\title{
Introduction to the Thematic Issue "Topical Research in the Field of Modern Social Sciences, Culture Studies and Art History"
}

\author{
Natalia P. Koptseva \\ Siberian Federal University \\ 79 Svobodny, Krasnoyarsk, 660041, Russia
}

Received 09.06.2019, received in revised form 03.07.2019, accepted 09.07.2019

The opening speech of the editor of the next issue of the Siberian Federal University Scientific Journal presents the main ideas that unite articles by different authors into a single, integral issue. The editor considers the conceptual and methodological foundations of the authors, highlights the main ideas and makes conclusions on the prospects of scientific themes.

Keywords: scientific journal, Siberian Federal University, Krasnoyarsk Territory, research problems, liberal arts, social sciences.

Research area: culturology.

Citation: Koptseva, N.P. (2019). Introduction to the thematic issue "Topical research in the field of modern social sciences, culture studies and art history". J. Sib. Fed. Univ. Humanit. soc. sci., 12(7), 1128-1131. DOI: 10.17516/1997-1370-0444.

We are pleased to present our readers with the new issue of the Humanities series of Siberian Federal University Journal dedicated to the results of the research in the most interesting areas of liberal arts, classical studies, migration studies and ethnic studies.

It would be right to start the overview of the publications of this issue with the article "The Sage and the Demos: the Intellectual within Athenian Cultural and Social Landscape of the Fifth and Fourth Centuries" by two remarkable authors: the famous antiquity researcher, philosopher, theologian and religious scholar Professor Roman Viktorovich Svetlov and no less significant antiquity researcher Professor Vasily Rabosh. In this article, the authors record the cultural moment of the emergence of an intellectual among other social actors. Intellectual activity as socially significant one appears in times of high classics in Athens. The article by R. Svetlov and V. Rabosh

(C) Siberian Federal University. All rights reserved

* Corresponding author E-mail address: decanka@mail.ru ORCID: 0000-0003-3910-7991 (Koptseva)

This work is licensed under a Creative Commons Attribution-NonCommercial 4.0 International License (CC BY-NC 4.0). 
for the first time determines the conditions under which intellectual activity can arise in general.

The high level set by this article is preserved in the work "Ironic Strategies of Postmodern Art Games" by the researcher from Saint-Petersburg, Leonid Aleksandrovich Menshikov. This is the second time pole of culture: the modern era associated with the concept of irony in ancient Athens. Leonid Menshikov, the leading art historian of modern Russia, reveals some relevant artistic processes, their gaming essence.

The theoretical work of L. Menshikov is supplemented in our issue with three articles from the "Three Pictures" series. The series is based on the research of outstanding artists of the $19^{\text {th }}-21^{\text {st }}$ centuries that began several years ago through the analysis of their three works.

Today we present the reader with three brilliant European artists of the $19^{\text {th }}-20^{\text {th }}$ centuries: Norwegian Edvard Munch (everyone knows his amazing picture "Scream"), Austrian Egon Schiele (an outstanding representative of the Viennese Modernism) and French Gustave Moreau (the author of symbolic works of art that combined myths and modern culture).

Ksenia Reznikova, Alexandra Sitnikova and Yulia Zamaraeva, the authors of the scientific article "Three Paintings by Egon Schiele: Ideas About the Essence of Art", study Egon Schiele's self-portraits, reveal the artist's tragic self-knowledge manifested in his famous works.

The "Three Pictures" project continues in the study of Yekaterina Sertakova, Natalia Leshchinskaia and Maria Kolesnik. These authors of the article "Three Paintings by Gustave Moreau: Myth, Religion, Creativity" consider the symbolism of Gustave Moreau in combination with the theory of cultural values. They also apply the method of philosophical art criticism and semiotic analysis constructing the ideological principles of the great French artist.

And finally, Natalia Seredkina, Anastasia Kistova and Natalia Pimenova's article "The Frieze of Life" by Edvard Munch: Philosophical and Art History Analysis" reveals the possibilities of philosophical and art analysis of the most complex contemporary Norwegian artist Edvard Munch, whose artistic language is simple and complex, symbolic and realistic at the same time.

Further, the theme of historical discoveries in the field of classical culture is continued by the article by the Chelyabinsk professors Natalia Parfentieva and Nikolai Parfentiev "Madonna of Demidovs" and "Madonna Stroganoff". The cultural and art history analysis of these researchers reveals the peculiarities of the socio-cultural 
process characteristic of the Southern Urals of the $19^{\text {th }}-21^{\text {st }}$ centuries. The contemporary viewer of outstanding works, which by the will of fate and the will of the great Ural patrons of art turned out to be in regional museums, should understand the significance of these artistic processes in our time. The difficulties of artistic communication "through the ages" are revealed in the article by N. V. Parfentieva and N. P. Parfentiev, famous Ural cultural and art historians through the analysis of classical works of art.

The ethnic theme continues in the studies of a whole number of authors of our issue. The team of Tomsk and Tuva researchers Choygan Sanchay, Maria Kukhta and Olga Khomushku in their article "Archetypical Symbols in the Modern Tuvan Culture" continue the theme of symbolism through the prism of ethnic modern Tuvan dance. The article solves the most difficult problem of the semiotic analysis of choreographic works of art at a high conceptual and methodological level.

Ethnic studies in the analysis of complex modern migration processes are revealed in the work by Moscow sociologists Anna Rocheva, Evgeni Varshaver and Nataliya Ivanova "Youth with Migrant Background: Are They Willing to Stay in Russia?". The authors use qualitative sociological methods and present the results of their field research that they conducted in various cities and regions of the modern Russian Federation. Scientists wanted to understand the differences between the migrants of the first generation and the ones of the second and third generations. Their conclusions are quite optimistic and scientifically based.

In the scientific article by an interregional group of authors from Chelyabinsk and Krasnoyarsk "The Structure of Economic Attitudes of the Youth - Representatives of The Indigenous Small-Numbered Peoples of the Arctic Zone of the Russian Federation: Results of a Pilot Study", researchers Ekaterina Zabelina, Svetlana Kurnosova, Irina Trushina, Vladimir Luzan and Natalia Koptseva examine modern ethnic processes associated with the characteristics of social groups of small indigenous peoples of the Arctic zone of the Russian Federation. The Krasnoyarsk Territory is also included in the Arctic zone of the Russian Federation and the processes that are rapidly developing here, need a serious expert assessment, scientific interdisciplinary research. This article allows to make well-considered political and economic decisions in accordance with the recommendations made by the authors.

The topic of ethnic studies of northern peoples continues in the scientific article "Cultural Originality ofZoological Definitions(Based on the Analysis of the Republic ofSakha(Yakutia)" by Yakut authors Ninel Malysheva, Alla Bozhedonova and Alina Vasilyeva. Modern Yakutia experiences the most interesting processes of ethnic and cultural identification associated 
with the active participation of various social groups in cultural processes. The peculiarity of the cultural Yakut space is presented in this article in the aspect of the unity of the historical and the logical, combined in specific cultural phenomena.

Various possibilities of modern social, cultural and art criticism studies are demonstrated in the scientific article "Symbolical Content for Regulatory Bases of Intonation Culture" by Kemerovo cultural studies experts Oksana Rtishcheva and Irina Shikaleva. This is a serious cultural study, where the authors expand the conceptual space of the modern theory of culture, developing new categories and revealing new content in the already established concepts.

A classic scientific method that never ceases to be the base for social and cultural research is the work with archival documents. Omsk authors Dmitry Petin and Sergey Naumov reconstruct the dynamics of military Siberian settlements based on the analysis of a specific military town. Their work is a thorough empirical research that has value for everybody studying the Siberian history and Russian practices of exploring complex Siberian space.

Therefore, this issue has united the authors applying the most modern and effective scientific methods in their research work: both theoretical and empirical. Each scientific article invites readers to an active discussion, and we sincerely hope to receive your feedback, comments and recommendations.

\title{
Вступление к тематическому номеру «Актуальные исследования в области современных социальных наук, культурологии и искусствоведения»
}

Н. П. Копцева

Сибирский федеральный университет Россия, 660041, Красноярск, пр. Свободный, 79

\begin{abstract}
Вступительное слово редактора очередного номера научного журнала Сибирского федерального университета представляет основные идеи, объединяющие статьи разных авторов в единый, целостный выпуск. Рассматриваются концептуальные и методологические основания авторов, выделяются главные тезисы, делается вывод о перспективности научной проблематики.
\end{abstract}

Ключевые слова: научный журнал, Сибирский федеральный университет, Красноярский край, научные проблемы, свободные искусства, социальные науки.

Научная специальность: 24.00.00 - культурология. 